\title{
Measurement of Heavy Metals/Metalloids Levels with Using Dytiscidae (Coleoptera) Species, Collected from Six Different Cities of Turkey
}

\author{
Zeynep AYDOĞAN ${ }^{1,2^{*}}$, Ümit İNCEKARA ${ }^{2}$, Ali GÜROL ${ }^{3}$, Mustafa Cemal DARILMAZ ${ }^{4}$
}

\begin{abstract}
This study was performed to determine the amount of some elements concentration in bodies of the aquatic insects. The contaminants, in six different polluted and non-polluted cities of Turkey, were determined with using predaceous diving beetles. Energy Dispersive X-Ray Fluorescence (EDXRF) spectroscopy was used for determining the concentrations of heavy metals/metalloids in the total body of the insects. Sixteen elements (Ca, Ti, V, Cr, Mn, Fe, Co, Ni, Cu, Zn, As, Se, Br, Rb, Sr, and $\mathrm{Pb}$ ) were measured quantitatively in all the samples. Two elements (In, Sn) were measured below the detection limits of EDXRF. Significant heavy metals/metalloids accumulation was seen in two cities and species. Comparison of the studied bio-monitors, Cybister lateralimarginalis showed significantly higher elements accumulation than the other species, so it may be considered as a more suitable species for assessment of heavy metals/metalloids pollution.
\end{abstract}

Keywords: Aquatic insects, EDXRF, heavy metals/metalloids, pollution.

\section{Türkiye’deki Altı Farklı Şehrin Ağır Metal/Metalloid Seviyesinin Dytiscidae (Coleoptera) Türleri Kullanılarak Ölçümü}

ÖZET: $\mathrm{Bu}$ çalışma sucul böceklerin vücutlarında biriken bazı elementlerin konsantrasyonunu belirlemek için yapıldı. Türkiye'deki temiz ve kirli olan altı farklı şehirdeki inorganik bulaşanlar, predatör dalgıç böcekleri kullanılarak belirlendi. Böceklerin vücudundaki ağır metal/metalloid seviyesini belirlemede enerji ayrışımlı X ışını floresan spektrometresi (EDXRF) kullanıldı. Tüm türlerde 16 element (Ca, Ti, V, Cr, Mn, Fe, Co, Ni, Cu, Zn, As, Se, Br, Rb, Sr ve Pb) nicel olarak ölçüldü. İki elementin (In, Sn) EDXRF'nin algılama sınırının altında olduğu görüldü. İki şehirde ve türde belirgin olarak ağır metal/metaloid birikimi gözlemlendi. Biyogözlemde kullanılan türler karşılaştırıldığında Cybister lateralimarginalis türü diğer türlere göre daha fazla birikim yapması nedeniyle ağır metal/metaloid takibinde daha uygun olacağı düşünüldü.

Anahtar Kelimeler: Sucul böcek, EDXRF, ağır metal/metalloid, kirlilik.

\footnotetext{
1 Zeynep AYDOĞAN (Orcid ID: 0000-0001-8859-2108),) Narman Vocational School, Atatürk University, Narman, Erzurum, Turkey,

2 Ümit İNCEKARA (Orcid ID: 0000-0002-3283-5841), Faculty of Science, Department of Biology, Atatürk University, Erzurum, Turkey,

${ }^{3}$ Ali GÜROL (Orcid ID: 0000-0001-9494-3533), Faculty of Science, Department of Physics, Atatürk University, Erzurum, Turkey,

${ }^{4}$ Mustafa Cemal DARILMAZ (Orcid ID: 0000-0003-2055-1224, mdarilmaz@yahoo.com, Faculty of Science, Department of Biology, Aksaray University, Aksaray, Turkey.

*Sorumlu Yazar/Corresponding Author: Zeynep AYDOĞAN, zeynep.aydogan@atauni.edu.tr

Geliş tarihi / Received: 13-12-2019 Kabul tarihi / Accepted: 17-04-2020
} 


\section{INTRODUCTION}

All elements are natural components of Earth crust and distributed in different concentrations in the atmosphere, lithosphere, hydrosphere, and biosphere but vehicle exhaust, mining activities, energy production, industrial metallurgic processes, and agricultural activities are increasing these elements concentration in an environment. Anthropogenic activities are greatly responsible for the changing, availability, cycling, and concentration of elements in nature. However, elements in the environment must be at acceptable intervals. If the limit is exceeded, environmental heavy element pollution begins when element concentrations exceed the self-renewal capacity of nature. In literature there are numerous studies about heavy elements in urban areas which indicate that they are persistent, spreading widely in the environment, pose threat to natural components and human health (Aydoğan et al., 2017; Ye et al., 2018). The term "heavy metal" was searched on the Web of Science (WOS) publication in number 5 360, 64575 and 88173 records in the year 1970-1990, 1990-2010 and 20102019 respectively. That is why, it is understood that element pollutions have been intensively studied and are one of the serious ecological problem in today's world due to their toxicity.

The term "heavy metals" have been defined in several ways in the field of chemistry, physics, law, medicine, biology and ecology. Biologist including environmental scientist use the term "heavy metal" as a connotation of toxicity and below or above level of certain element's threshold can cause environmental or health problems.

To evaluate the environment by biologically is not a new phenomenon. Environmental monitoring with using biota is important to determine negative anthropogenic impact on the environment. Their presence, absence or changing numbers of insects give and idea when evaluate a certain environment. There are some mostly used and suggested organisms when surveying the environment; plants and their organs (Baldantoni et al., 2018), bivalve (Ragi et al., 2017), zooplankton (Itigilova et al., 2016), mosses (Liu et al., 2016), algae (Chu et al., 2019), fish and insects (Aydoğan et al., 2017).

With approximately 4300 named species, Predaceous Diving Beetles or Dytiscids are one of the largest families of freshwater insect species. Both larvae and adults of these species inhabit various types of aquatic habitats and are important predators on other invertebrates and vertebrates (Miller and Bergsten, 2016; Yee, 2016). The objective of this research was to evaluate and determine the heavy element accumulation with using some Dytiscid beetles which are living different cities of Turkey.

\section{MATERIALS AND METHODS}

\section{Study Areas and Sampling}

In the present study, the accumulation of sixteen heavy metal/metalloids in some aquatic beetles (Dytiscidae) was evaluated. For this purpose, six Dytiscidae species were collected from six cities of Turkey (Aydın, Denizli, Uşak, Afyon, Kütahya, Erzincan). Samples were collected from running water, permanent and temporal aquatic habitats in places where aquatic species could be observed. The collection was made by means of a $1 \mathrm{~mm}$ pores sieve, and then the beetles were killed with ethyl acetate and stored in bottles until identification in the laboratory. Before identification samples were cleaned with a brush then dissected under a stereomicroscope in the laboratory. Aedeagophores of the beetles were used for identification. Six species belonging to four genera of Dytiscidae were identified. These species are as follows: Platambus lunulatus (Fischervon Waldheim, 1829); Agabus biguttatus (Olivier, 
1795); Agabus conspersus (Marsham, 1802); Cybister lateralimarginalis De Geer, 1774; Cybister tripunctatus (Olivier, 1795); Dytiscus marginalis Linnaeus 1758.

Sampling point 1- P. lunulatus collected from Kemaliye, Çevlik River (Erzincan). There is no settlement around at the sample point. Platambus lunulatus collected from here.

Sampling point 2- A. biguttatus collected from Çardak, Değirmen creek (Denizli). This location is 49 $\mathrm{km}$ far from Denizli. There is a dam on the Değirmen creek, which used for irrigation.

Sampling point 3- A. conspersus collected from Banaz, Ahat Village (Uşak). The location has $41 \mathrm{~km}$ distance to Uşak. Agricultural activity and traffic are not intense.

Sampling point 4- $C$. lateralimarginalis sample collected from Eber Lake (Afyon). Eber Lake is a grade 1 natural site area and is twelfth biggest lake of Turkey. This lake was one of the important wetlands in Turkey but now it has been polluted by domestically, milk, sugar and alkaloid industry; all of which contribute to pollution at the sample point.

Sampling point 5- C. tripunctatus sample collected from Söke, Azap Lake (Aydın). This lake is rich in terms of biodiversity, but in the year 2007, the lake was dry up and polluted with agricultural chemicals. Sampling point 6- Türkmen Mountain (Söğüt Plateau) is $28 \mathrm{~km}$ far from Kütahya. The sampling point is a stream that is near the road. There is a small village near it. Possible pollution sources are domestic, agricultural and car exhaust. D. marginalis collected from here.

The GPS information (coordinates, altitude) of sample locations is given in Table 1. Map of studied cities and collected species is given in the Figure 1.

Table 1. Dytiscidae samples and their station information

\begin{tabular}{llll}
\hline Station Number & Coordinates & Altitude (m) & Sample Name \\
\hline 1- Erzincan & $39^{\circ} 14^{\prime} 47^{\prime \prime N} / 38^{\circ} 30^{\prime} 07^{\prime \prime} \mathrm{E}$ & 866 & Platambus lunulatus \\
2- Denizli & $37^{\circ} 41^{\prime} 294^{\prime \prime N} / 29^{\circ} 37^{\prime} 290^{\prime \prime} \mathrm{E}$ & 921 & Agabus biguttatus \\
3- Uşak & $38^{\circ} 39^{\prime} 331^{\prime \prime N} / 29^{\circ} 46^{\prime} 825^{\prime \prime} \mathrm{E}$ & 958 & Agabus conspersus \\
4- Afyon & $38^{\circ} 36^{\prime} 875^{\prime \prime} \mathrm{N} / 31^{\circ} 09^{\prime} 611^{\prime \prime} \mathrm{E}$ & 973 & Cybister lateralimarginalis \\
5- Aydın & $37^{\circ} 35^{\prime} 61^{\prime \prime} \mathrm{N} / 27^{\circ} 26^{\prime} 28^{\prime \prime} \mathrm{E}$ & 40 & Cybister tripunctatus \\
6- Kütahya & $39^{\circ} 23^{\prime} 672^{\prime \prime} \mathrm{N} / 30^{\circ} 18^{\prime} 941^{\prime \prime} \mathrm{E}$ & 1414 & Dytiscus marginalis \\
\hline
\end{tabular}

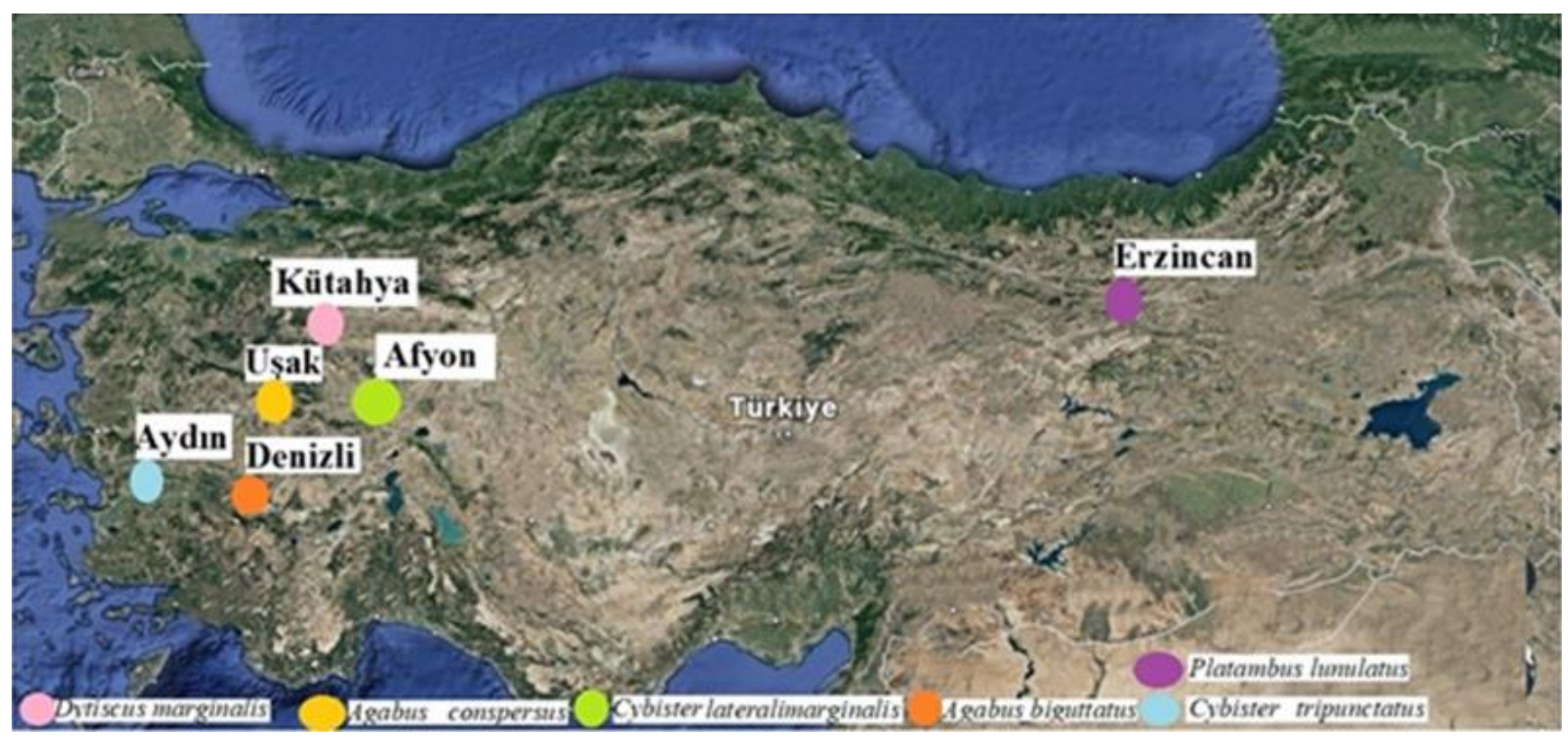

Figure 1. The map of studied cities and collected species 


\section{EDXRF Analysis}

Heavy element measurements were carried out using an EDXRF spectrometer. The following 16 elemental concentrations were determined by means of this process: $\mathrm{Ca}, \mathrm{Ti}, \mathrm{V}, \mathrm{Cr}, \mathrm{Mn}, \mathrm{Fe}, \mathrm{Co}, \mathrm{Ni}, \mathrm{Cu}$, $\mathrm{Zn}, \mathrm{As}, \mathrm{Se}, \mathrm{Br}, \mathrm{Rb}, \mathrm{Sr}$ and $\mathrm{Pb}$. The results of the analyses are given in Table 2. Heavy element analyses were done as described in Aydoğan et al. (2017; 2018). Firstly, the samples were dried in an oven at $80^{\circ} \mathrm{C}$ during $36 \mathrm{~h}$, then pulverized and applied five-ton pressure to make $13 \mathrm{~mm}$ diameter tablets of each sample. $59.5 \mathrm{keV}$ photons irradiated the insect samples which emitted by $1 \mathrm{Ci}^{241} \mathrm{Am}$ radioactive source. The irradiation time was $43.200 \mathrm{~s}$. Source/Sample distance was $35.5 \mathrm{~mm}$. The measurements were carried out under vacuum. The spectral data were stored on disks, and the concentration of elements in each samples were determined by WinAXIL software (Canberra) and Win Fund software package (Canberra), which use the Fundamental Parameters Method (FPM) for quantitative analysis.

\section{RESULTS AND DISCUSSION}

Element concentrations in an area has been generally measured chemically, physically and biologically. Any kind of organisms reflects the quality of the environment where they live. In this study, elements monitoring were evaluated by biologically. Dytiscidae are distributed throughout in Turkey. In the present study six different aquatic beetles were recorded at six different cities in Turkey (Aydın, Denizli, Uşak, Afyon, Kütahya and Erzincan). According to the results heavy element concentrations of in these cities' insects show significantly variability. Heavy element content of the station 2, 3, 5 and 6 have lower degree than the other two cities' station. The recorded insects are Platambus lunulatus, Agabus biguttatus, Agabus conspersus, Cybister lateralimarginalis, Cybister tripunctatus, Dytiscus marginalis. Measured heavy element levels in the insect samples are given in Table 2. Due to the low number of insects, the study's results could not be evaluated as statistically.

Table 2. Mean heavy element concentrations in the Dytiscidae samples (ppm)

\begin{tabular}{lcccccc}
\hline $\begin{array}{c}\text { Heavy } \\
\text { Element }\end{array}$ & $\begin{array}{c}\text { Dytiscus } \\
\text { marginalis }\end{array}$ & $\begin{array}{c}\text { Cybister } \\
\text { lateralimarginalis }\end{array}$ & $\begin{array}{c}\text { Cybister } \\
\text { tripunctatus }\end{array}$ & $\begin{array}{c}\text { Agabus } \\
\text { biguttatus }\end{array}$ & $\begin{array}{c}\text { Agabus } \\
\text { conspersus }\end{array}$ & $\begin{array}{c}\text { Platambus } \\
\text { lunulatus }\end{array}$ \\
\hline $\mathbf{C a}$ & 0.824 & 329.66 & 1.079 & 0.711 & 1.061 & 50.91 \\
$\mathbf{T i}$ & 0.424 & 84.95 & 0.438 & 0.430 & 0.390 & 13.97 \\
$\mathbf{V}$ & 0.313 & 57.37 & 0.459 & 0.264 & 0.290 & 9.458 \\
$\mathbf{C r}$ & 0.262 & 43.17 & 0.285 & 0.201 & 0.223 & 5.630 \\
$\mathbf{M n}$ & 0.293 & 30.09 & 0.275 & 0.161 & 0.234 & 2.912 \\
$\mathbf{F e}$ & 0.217 & 19.50 & 0.226 & 0.120 & 0.134 & 1.695 \\
$\mathbf{C o}$ & 0.202 & 93.97 & 0.239 & 0.161 & 0.189 & 1.828 \\
$\mathbf{N i}$ & 0.174 & 71.135 & 0.158 & 0.132 & 0.137 & 1.393 \\
$\mathbf{C u}$ & 0.174 & 44.43 & 0.129 & 0.130 & 0.110 & 0.940 \\
$\mathbf{Z n}$ & 0.106 & 29.63 & 0.122 & 0.089 & 0.094 & 0.550 \\
$\mathbf{A s}$ & 0.273 & 40.60 & 0.219 & 0.225 & 0.175 & 0.603 \\
$\mathbf{S e}$ & 0.077 & 12.22 & 0.057 & 0.055 & 0.049 & 0.148 \\
$\mathbf{B r}$ & 0.055 & 6.96 & 0.061 & 0.050 & 0.052 & 0.217 \\
$\mathbf{R b}$ & 0.046 & 4.21 & 0.039 & 0.038 & 0.040 & 0.067 \\
$\mathbf{S r}$ & 0.036 & 4.07 & 0.037 & 0.035 & 0.030 & 0.075 \\
$\mathbf{P b}$ & 0.566 & 79.9 & 0.459 & 0.469 & 0.362 & 1.247 \\
\hline
\end{tabular}

The results reflects a clear influence of heavy metal pollution in the areas. Because concentration of the sixteen elements ( $\mathrm{Ca}, \mathrm{Ti}, \mathrm{V}, \mathrm{Cr}, \mathrm{Mn}, \mathrm{Fe}, \mathrm{Co}, \mathrm{Ni}, \mathrm{Cu}, \mathrm{Zn}, \mathrm{As}, \mathrm{Se}, \mathrm{Br}, \mathrm{Rb}, \mathrm{Sr}, \mathrm{Pb}$ ) in all stations were measured all of the aquatic insects. Especially $\mathrm{Ti}, \mathrm{V}, \mathrm{As}, \mathrm{Br}, \mathrm{Rb}, \mathrm{Sr}$ and $\mathrm{Pb}$ are not associated with 
an organism's body mineral content and have no any biological importance. Every insects were accumulated these elements in varying concentration. This result should be due to difference in the environmental conditions and insects' life. Analyses revealed that Eber Lake, which is grade 1 natural site area and is twelfth biggest Lake of Turkey, was the most polluted with all elements except $\mathrm{Br}, \mathrm{Rb}$, Sr. Higher concentration of accumulation was measured at $C$. lateralimarginalis in sample point 4 and at $P$. lunulatus in sample point 1 . It can be thought that $C$. lateralimarginalis can managed to survive even the low environmental conditions. The element concentration showed a general trend of $\mathrm{Ca}>\mathrm{Co}>\mathrm{Ti}>\mathrm{Pb}>\mathrm{Ni}>\mathrm{V}>\mathrm{Cu}>\mathrm{Cr}>\mathrm{As}>\mathrm{Mn}>\mathrm{Zn}>\mathrm{Fe}>\mathrm{Se}>\mathrm{Br}>\mathrm{Rb}>\mathrm{Sr}$ in $C$. lateralimarginalis and $\mathrm{Ca}>\mathrm{Ti}>\mathrm{V}>$ $\mathrm{Cr}>\mathrm{Mn}>\mathrm{Co}>\mathrm{Fe}>\mathrm{Ni}>\mathrm{Pb}>\mathrm{Cu}>\mathrm{As}>\mathrm{Zn}>\mathrm{Pb}>\mathrm{Br}>\mathrm{Sr}>\mathrm{Rb}$ in $P$. lunulatus. There is a dam on Değirmen creek at sample point 2, and the creek is using for irrigation. Accumulation levels of the insects in this location are not high and not pose a health problem for the field. Sample point 5 has the richest biodiversity than the other locations and heavy element levels are not at high level.

When evaluate the results, possible reason for the element accumulation in $C$. lateralimarginalis and $P$. lunulatus may be related to; Ti can be found everywhere like water, soil and organisms and it is used in industry and food industry intensively. Vanadium spread to atmosphere mainly from fossil fuels. Chromium toxicity increase in aquatic organisms when temperature goes up, $\mathrm{pH}$ and salinity go down. Beside to metallurgical industry, Manganese mainly has been used as pesticide, fertilizer and livestock supplement. Iron is one of the most widespread elements of lithosphere and has been used in industry intensively. Source of Cobalt in the studied area might be due to fossil fuels. Nickel sources might be industrial wastes and fossil fuels. Acidity increases mobility of Ni. The high concentration of Zinc, Arsenic, Bromium and Copper in the location 4 may be attributable to agricultural activities, sugar industry and intensive vehicular traffic in the surroundings. Lead is toxic for living creature, so there is no safe limit for lead. If it is enter the human body, it accumulates in brain, liver, kidney and bone. It can be found in soil naturally but most of anthropogenic activities cause release of lead in the environment (ATSDR, 2000; Solomon, 2008; Kabata-Pendias, 2010).

As a consequence of agriculture, industry, vehicle emissions, tyre and brake abrasion, lead to principally continuous input of the element in the urban environment. Industries together with the high vehicular traffics volume roads are mainly responsible for generalized element pollution, as in the similar studies (Solomon, 2008), in the present study the highest element concentrations were found in the industrial district. Eber Lake was one of the important wetland in Turkey but now it has been polluted by domestically, milk, sugar and alkaloid industry (Aşç1 et al, 2009). In sample point 1, where the human activity is limited, has heavy element concentration in terms of $\mathrm{Ca}, \mathrm{Ti}, \mathrm{V}, \mathrm{Cr}, \mathrm{Mn}, \mathrm{Fe}, \mathrm{Co}, \mathrm{Ni}$ and $\mathrm{Pb}$. Atmospheric transportation, water and soil element concentrations may responsible for that element accumulation level.

In the selected locations there is no any heavy element evaluation studies that have been done before. Thus, the present study's results will serve a guideline for further sampling, and also will be a baseline for the estimation of future trends.

\section{CONCLUSION}

Aquatic insects are one of the inseparable part of the aquatic ecosystems. If there is a chemical pollution in an environment, the pollution will reach an organism from one to another in the food web, in the end to human. Therefore, protecting an environment means protect the human life. The study findings point out that in sample point 1 and 4 represent an important source of inorganic pollutants and are the most polluted stations among the studied locations. Different concentrations of heavy elements 
in the insects indicate that these insects continue to live at these studied habitats even though heavily contaminated areas. In literature some organisms are thought as bio-monitor, to evaluate the environmental quality (Aşçı et al., 2009; Aydoğan et al., 2017; Baldantoni et al., 2018). It can be said that in this study, the insects (C. lateralimarginalis, $P$. lunulatus) tolerant to pollution and accumulate the elements at higher concentration, thus can be an appealing tool for element contamination studies.

Pollution causes major declines in biota (Yuan et al., 2018). On account of this, element accumulation degree in the examined aquatic beetles might enrich over time and pose a threat in future. In this study, the stations with low heavy metal content currently do not pose a threat to their habitat function. But, these metal contents may inclined to enrich over time.

An ecosystem consist of biotic and abiotic factors where they interact each other. Anthropogenic inputs in the sampling location does not draw a clear pollution scenario, the results only reflecting element concentration at the aquatic insects. Hence, the pollution was only evaluated by biologically. Environmental heavy element contamination studies should be assessed with the biota and their nonliving surroundings. The study needs further data about evaluation of element concentration in soil, sediment and water where the insects live in. Besides, in order to derive knowledge during the time, long term sampling and measurements must be regularly done both biotic and abiotic samples. Besides, inorganic elements and also organic pollutants (organochlorine, organophosphate etc.) should be observed. In addition to measured sixteen elements, In and Sn (ppm) measured in all the insects but their concentrations were below the EDXRF detection limit.

\section{ACKNOWLEDGEMENTS}

We thank the anonymous reviewers for their contributions to the manuscript. We have no conflicts of interest to disclose. This research did not receive any specific grant from funding agencies in the public, commercial, or not-for-profit sectors.

\section{REFERENCES}

ATSDR, 2000. Toxicological profile for manganese, www.atsdr.cdc.gov/toxprofiles/tp. (Accessed 10 May 2019) Aşçı F, Korcan Fıçıcı E, Konuk M, 2009. Eber ve Karamık Göllerindeki Kontaminasyonun Belirlenmesine Yeni Bir Yaklaşım. Kafkas Üniversitesi Fen Bilimleri Enstitüsü Dergisi, 2 (1):1-4.

Aydoğan Z, Şişman T, İncekara Ü, Gürol A, 2017. Heavy Metal Accumulation in Some Aquatic Insects (Coleoptera: Hydrophilidae) and Tissues of Chondrostoma Regium (Heckel, 1843) Relevant to Their Concentration in Water and Sediments from Karasu River, Erzurum, Turkey. Environmental Science Pollution Research, 24 (10): 9566-9574. doi.org/10.1007/s11356-017-8629-x

Aydoğan Z, Gürol A, İncekara Ü, 2018. Heavy Element Accumulation in Aquatic Beetles of the Genus Enochrus (Coleoptera: Hydrophilidae) in Erzurum Province. Journal Environmental Pollution Control, 1(1): 101.

Baldantoni D, Bellino A, Lofrano G, Libralato G, Pucci L, Carotenuto M, 2018. Biomonitoring of nutrient and toxic element concentrations in the Sarno River through aquatic plants. Ecotoxicology and Environmental Safety, 148: 520-527.

Chu WL, Dang NL, Kok YY, Yap KSI, Phang SM, Convey P, 2019. Heavy metal pollution in Antarctica and its potential impacts on algae. Polar Science, 20: 75-83.

Itigilova MT, Tashlykova NA, Afonina EY, 2016. Heavy metals in phyto-and zooplankton of Lake Kenon (Transbaikalia). Contemporary Problems of Ecology, 9(6): 783-789.

Kabata-Pendias A, 2010. Trace elements in soils and plants ( $4^{\text {th }}$ ed.). CRC press, $548 \mathrm{p}$.

Liu C, Zhou P, Fang Y, 2016. Monitoring airborne heavy metal using mosses in the City of Xuzhou, China. Bulletin of Environmental Contamination and Toxicology, 96(5): 638-644. 
Miller KB, Bergsten J, 2016. Diving beetles of the world: Systematics and biology of the Dytiscidae. JHU Press, $336 \mathrm{p}$.

Ragi AS, Leena PP, Cheriyan E, Nair SM, 2017. Heavy metal concentrations in some gastropods and bivalves collected from the fishing zone of South India. Marine Pollution Bulletin, 118(1-2): 452-458.

Solomon F, 2008. Impacts of metals on aquatic ecosystems and human health. Environment and Communities, 14-19. www.mining.com_(Accessed 10 May 2019)

Ye P, Hao X, Cao Y, 2018. Analysis on Ecological Protection of Urban Wetland. Natural Resources Conservation and Research, 1(1): 1-7.

Yee DA, 2016. Ecology, Systematics, and the Natural History of Predaceous Diving Beetles (Coleoptera: Dytiscidae). Springer. DOI: https://doi.org/10.1007/978-94-017-9109-0.

Yuan X, Jiang Y, Yan Z, 2018. On the Causes of the Decrease of Biodiversity and the Countermeasures. Natural Resources Conservation and Research, 1(1): 15-21. 